\title{
Ters-Yüz Sınıf Modelinin Etkin Vatandaşlık Öğrenme Alanının Öğretiminde Kullanılmasının Öğrencilerin Akademik Başarılarına Etkisi1
}

DOI: 10.26466/opus.658882

Melike Söğüt* - Suat Polat ${ }^{* *}$

* Yüksek Lisans Öğrencisi, Ağrı İbrahim Çeçen Üni.Sosyal Bilimler Enstitüsü, Ağrı/Türkiye

E-Posta: sogutmelike224@gmail.com

ORCID: $\underline{0000-0002-7743-6350}$

** Dr. Öğr. Üyesi Ağrı İbrahim Çeçen Üniversitesi, Eğitim Fakültesi, Ağrı/Türkiye

E-Posta: spolat@agri.edu.tr

ORCID: $\underline{\text { 0000-0001-9286-8840 }}$

Öz

Bu araştırmanın amacı, ters-yüz sınıf modelinin Ortaokul 5. sinıf Sosyal Bilgiler dersi "Etkin Vatandaşlık" öğrenme alanının öğretiminde kullanılmasının öğrencilerin akademik başarılarına etkisini ve sürece ilişkin öğrenci görüşlerini tespit etmektir. Araştırmada, karma yöntem desenlerinden birisi olan iç içe desen kullanılmıştır. Araştırmanın nicel boyutu kontrol gruplu ön test son test yarı deneysel desen ile nitel boyutu betimsel yöntem ile yürütülmüştür. Deney grubunda etkin vatandaşlık"öğrenme alanının öğretimi ters-yüz sınıf modeli ile kontrol grubunda ise MEB'in müfredata uygun şekilde belirlediği süreç ile yapılmıştır. Araştırmanın evrenini, Ağrn il merkezinde yer alan ortaokullarda 20182019 eğitim-öğretim yılında öğrenim gören tüm öğrenciler, örneklemini ise ilgili evrenden rastgele seçilen bir ortaokulda öğrenim gören toplam 88 öğrenci oluşturmaktadır. Öğretim sürecine ilişkin öğrenci görüşlerini tespit etmek amactyla da veriler deney grubunda yer alan 11 öğrenciden toplanmıştır. Çalışmada veriler, akademik başarı testi ve yarı yapılandırılmış görü̧̧me formu ile elde edilmiştir. Akademik başarı testi ile elde edilen veriler SPSS istatistik programı ile analiz edilirken, yar yapılandırılmış görüşme formu ile elde edilen veriler ise betimsel analiz yöntemi ile çözümlenmiştir. Araştırmanın sonucunda ters yüz sını modelinin, MEB'in müfredata uygun şekilde belirlediği sürece göre akademik başarıyı arttırdığı tespit edilmiştir. Yapılan görüşmede katılımcıların, ters yüz sınıf modeli ile ilgili eksikliklerin giderilmesi sonucunda modelin daha verimli olacağına dair görüşler öne sürdükleri belirlenmiştir.

Anahtar Kelimeler: Sosyal Bilgiler, ters yüz sınıf modeli, akademik başarı, etkin vatandaşlık

\footnotetext{
${ }^{1}$ Bu çalışma, Sosyal bilgiler 5. sınıf etkin vatandaşlık öğrenme alanının ters-yüz sınıf modeline göre işlenmesinin akademik başarıya etkisi adlı yüksek lisans tezinden üretilmiştir
} 


\title{
The Effect of Using the Flipped Classroom Model in Teaching Active Citizenship Learning Area on Students' Academic Achievement
}

*

\begin{abstract}
The aim of this study is to determine the effect of using the flipped classroom model in teaching the "Active Citizenship" learning area in the Secondary School 5th grade Social Sciences course and the students' views on the process. In the research, the embedded design, one of the mixed-method designs, was used. The quantitative dimension of the research was carried out with a quasi-experimental design with pre-test and post-test control group, and the qualitative dimension was carried out with the descriptive method. In the experimental group, teaching the "effective citizenship" learning area was performed through the flipped classroom model and in the control group, it was performed with the process determined by the Ministry of National Education in accordance with the curriculum. The population of the research consists of all students receiving education in the 2018-2019 academic year in secondary schools located in the city center of A $\breve{g} r$, and the sample of the study consists of a total of 88 students receiving education in a secondary school randomly selected from the relevant population. Data were collected from 11 students in the experimental group in order to determine student views regarding the teaching process. In the study, data were obtained through an academic achievement test and a semistructured interview form. While the data obtained through the academic achievement test were analyzed with the SPSS statistical program, the data obtained through the semi-structured interview form were analyzed with the descriptive analysis method. As a result of the research, it was determined that the flipped classroom model increases academic achievement compared to the process determined by the Ministry of National Education in accordance with the curriculum. In the conducted interviews, it was seen that the participants suggested opinions regarding that the model will be more efficient if the imperfections related to the flipped classroom model are corrected.
\end{abstract}

Keywords: Social Studies, flipped classroom model, academic achievement, active citizenship 


\section{Giriş}

21. yüzyıl, insanı merkeze alan birçok problemin olduğu bir çağ olarak görülmektedir. Bu problemlerin merkezinde ise bireyin yapmış olduğu fiiller yer alır. Toplumu oluşturan bu bireylerin sorunlarının temelinde eğitim yer almaktadır. Bu yüzden eğitim sistemi, eğitim programı ve eğitim kurumunu oluşturan yöneticiler sürekli olarak sorgulanmakta ve değişmektedir (Şiş̧man, 2012). Bilim ve teknolojinin hızla gelişmesi eğitim sistemini etkilemiştir. Buna göre toplumu oluşturan bireylerin içinde bulunduğumuz çağa uygun olarak yetiştirilmesi amaçlanmıştır. Bu konuda mevcut eğitim programı değiştirilerek, düşünen, sorgulayabilen, yaratıcı ve sorunlara çözüm üretebilen bireyler yetiştirilmektedir (Yavuz ve Çoşkun, 2008).

Y kuşağı olarak adlandırılan, yeni nesil öğrenci profili, geleneksel yöntemlerle uygulanan eğitim sistemini sıkıcı bularak, artık teknolojinin içinde bulunduğu eğitim sistemini benimsemektedir. Bu yüzden eğitim sisteminde, bilgisayar, tablet ve internet kullanımı yaygınlaşmıştır. Böylece bilgiye her an ve her yerde ulaşmak mümkün olmuştur (Serçemeli, 2016). Eğitimde teknolojik yeniliklerin yaygınlaşması ile birlikte internet ve bilgisayar tüm öğrenme alanlarımızda kullanılmaya başlanmıştır. Yeni ve farklı bir öğrenme modeli olan ters yüz sınıf modelinin uygulanmasında da teknolojik araç gereçlere ihtiyaç duyulur (Kara, 2016).

Ters yüz kavramı; geleneksel olarak sınıf içerisinde yapılan dersin evde, evde yapılan ödevlerin ise sinfta yapılmasıdır (Bergmann ve Sams, 2012). Başka bir ifadeyle sınıfta eğitmen tarafından verilen dersin sınıf dışında öğrenci tarafından yapılması, evde yapılan ev ödevlerinin ise sınıfta rehber eşliğinde yapılmasına ters yüz sınıf modeli denir.

Ters yüz sınıf modeli; Colorado' da bulunan ve woodlank park lisesinde görev yapan Bergmann ve Sams'in, dersi kaçıran öğrencileri için çözüm arayışlarına başlamasıyla ortaya çıkmıştır. İlk olarak dersi kaçıran öğrencileri için canlı ders hazırlayarak öğrencilere dersin erişimi açılmıştır. Bu ders öncesinde de müfredata uygun videolar hazırlanmıştır. Hazırlanan bu videolar çeşitli bağlantılar ile öğrencilere iletilerek öğrencilerin eksiklikleri giderilmiştir (Bregmann ve Sams, 2012). Dersi kaçıran öğrencilerin eksiklerinin giderilmesi ve öğrenmelerine yardımcı olabilmek için çözüm olarak başlatılan model, öğretme ile öğrenmeye yenilikçi olan küresel bir yaklaşıma dönüştü 
(Philips ve Trainor, 2014). Bu ve buna benzer yeni yaklaşımların ortaya çıkması ile eğitim ve öğretimde kalıcılık da artmıştır. Böylece mevcut eğitim sisteminde kullanılan yaklaşımlar yerini yenilikçi yaklaşımlara bırakmıştır.

Son yıllarda, öğretmenin otoriter olduğu geleneksel eğitim anlayışı önemini kaybetmektedir. Yerini bireyin daha fazla sorumluluk sahibi ve daha aktif olduğu yaklaşımlar benimsenmiştir. Bu yaklaşımı temel alan modellerden birisi de ters yüz sınıf modelidir. Geleneksel modelde, konunun aktarılması, bireye kavratılması sınıf içerisinde, pekiştirilmesi ise sınıf dışında gerçekleşmektedir. Ters yüz sınıf modelinde ise bilginin aktarılması ve kavratılması sınıf dışında, konunun pekiştirilmesi ise rehber gözetiminde sınıf içerisinde yapılmaktadır (Gülş̧en ve Otacıoğlu, 2017). Aşağıda geleneksel model ile ters-yüz sınıf modelinin özellikleri belirgin bir şekilde verilmiştir:

\section{Geleneksel model;}

- $\quad$ Öğretmen ve konu merkezlidir.

- $\quad$ Öğretmen konuları anlatır ve öğrenci anlatılanları not alır.

- Derste öğrenci pasif katılımcıdır.

- $\quad$ Öğretmen öğrenci iletişimi genellikle tek yönlüdür.

- Dersin pekiştirilmesi aşaması sınıf dışında yapılacak ödevlere bırakılır.

Ters yüz sinıf modeli ise;

- Ö̆̆renci merkezli bir öğrenme anlayışıdır.

- Ders saatleri pasif dinleme ve sade bilgi aktarımı yerine öğrenci ve öğretmen açısından daha bol etkinlikli ve katılıml geçmektedir.

- Grup halinde öğrenmeler desteklendiğinden sorumluluk alma, işbirliği yapabilme ve grupla ortak bir ürün oluşturabilme gibi olumlu etkiler yaratmaktadır.

- Farkli öğrenme stillerine hitap etmektedir.

- Daha zor görevler sinıf ortamında yapılırken, teorik bilgi evde öğrenilir.

- Teknolojik araçlar eğitim sürecinde olmazsa olmazlardır (Dursunlar, 2018).

Sosyal Bilgiler dersinde yapılan ezberciliği ortadan kaldırmak ve öğrencilerin eğlenerek öğrenebileceği bir ders haline getirmek amaçlanmıştır (Ata, 2012). Sosyal Bilgiler dersinde geleneksel yöntemler ile ders anlatmak bireylerin derse ilgisini azaltabilir. Bu durum ters yüz sınıf modeli ile ortadan kaldırılabilir. Sosyal Bilgiler dersinde öğrenme etkililiğini arttırmak için öncelikle müfredatın yoğunluğundan kaynaklanan zamansal sorun çözülmelidir. Ters yüz sınıf modelinde dersin evde yapılması ile bu sorun ortadan kalkar 
ve sınıf içerisinde daha çok etkinlik yapılarak öğrenme etkililiği sağlanabilir (Karaman, 2018).

Literatür incelendiğinde Sosyal Bilgiler dersinde, ters yüz sınıf modelinin kullanımı ile ilgili çalışmalara rastlamak mümkündür (Akbaba ve Erdoğan, 2019; Dursunlar, 2018; Erdoğan, 2018; Karaman, 2018; Gökdemir, 2018;). Bu çalışmanın amacı Sosyal Bilgiler 5. sınıf dersinde etkin vatandaşlık öğrenme alanının ters-yüz sınıf modeline göre işlenmesinin öğrencilerin akademik başarısına etkisini incelemektir. Bu çalışma ile Sosyal Bilgiler dersini farklı bir modelle işleyerek dersin kalıcllı̆̆ ve öğrencilerin derse ilgisi arttırılmaya çalışılmıştır. Bu alanda ters yüz sınıf modeli ile ilgili çalışmaların sayıca yetersiz olmasından dolayı alana katkı sağlayacağı düşünülerek bu çalışma yapılmıştir.

Problem Durumu: Ters-yüz sinif modelinin Sosyal Bilgiler 5. sinıf Etkin Vatandaşlık öğrenme alanının öğretiminde kullanılmasının öğrencilerin akademik başarılarına etkisi var mıdır?

\section{Araştırmanin Alt Problemleri:}

- Kontrol ve deney gruplarını ön test ve son test ortalamaları arasında anlamlı bir fark var midır?

- Kontrol ve deney gruplarını ön test ve son test ortalamaları arasında anlamlı bir fark var midır?

- Cinsiyet değişkenine göre kontrol ve deney grubunda bulunan öğrencilerin ön test ve son test başarı puanları arasında anlamlı bir fark var midır?

- Gelir durumlarına göre kontrol ve deney grubunda bulunan öğrencilerin ön test ve son test başarı puanları arasında anlamlı bir fark var midir?

- İnternet kullanma durumlarına göre kontrol ve deney grubunda bulunan öğrencilerin ön test ve son test başarı puanları arasında anlamlı bir fark var midır?

- Yerleşim yeri durumlarına göre kontrol ve deney grubunda bulunan ögrencilerin ön test ve son test başarı puanları arasında anlamlı bir fark var midır? 
- Anne eğitim düzeylerine göre kontrol ve deney grubunda bulunan öğrencilerin ön test ve son test başarı puanları arasında anlamlı bir fark var midır?

- Baba eğitim düzeylerine göre kontrol ve deney grubunda bulunan öğrencilerin ön test ve son test başarı puanları arasında anlamlı bir fark var midır?

- Katılımcların ters yüz sınıf modeli ile ilgili önerileri nelerdir?

- Katılımcların, ters yüz sınıf modelinin derse katkısı ile ilgili görüşleri nelerdir?

- Katılımciların izledikleri videoların faydalı olup olmadığına dair görüşleri nelerdir?

- Katılımcların ters yüz sınıf modeli ile işlenen konunun kalıcılı̆̆ına ilişkin görüşleri nelerdir?

- Katılımciların, ters yüz sınıf modelinin olumlu ve olumsuz yönleri ile ilgili görüşleri nelerdir?

\section{Yöntem}

Araştırmada karma araştırma yöntemlerinden, iç içe karma desen kullanılmıştır. Karma araştırma yöntemi nicel veriler ile nitel verilerin birleşmesiyle ortaya çıkan bir yöntemdir. Verilerin sıralı ya da birleşik kullanılması ile ana fikrin verilerin birinde daha kapsamlı olarak ele alınmasını içeren desene iç içe karmaşık desen denir (Creswell, çev; Bütün, 2014). Karma araştırma kapsamında nicel ve nitel araştırma yöntemlerinden faydalanılmıştır. Nicel araştırma, gerçekliğin bağımsız ve tarafsız olarak gözlenip ölçülerek, analiz edildiği bir araştırma yöntemidir (Büyüköztürk, Kılıç Çakmak, Akgün, Karadeniz ve Demirel, 2016). Araştırmanın nicel aşamasında nicel araştırma yöntemlerinden yarı deneysel model kullanılmıştır. Deneysel araştırmada birçok desen kullanılır ama en çok kullanılan ise iki gruptan oluşan desenlerdir. Bu grupların birine kontrol grubu adı verilirken diğerine de deney grubu adı verilir (Özmen, 2014). Bu çalışma da iki gruptan oluşmuştur. Kontrol grubunda geleneksel yöntemlerle ders işlenirken, deney grubunda ters yüz sınıf modeli ile ders işlenmiştir. Nitel araştırma, nitel verilerin bir araya getirilmesi ile oluşan bir yöntemdir (Christensen, Johnson ve Turner, 2015). Nitel araştırma ile veriler; dokümanlar, gözlemler ya da görüşme yolu ile elde edilir. Bu çalış- 
manın nitel aşamasında ise betimsel yöntem kullanılmıştır. Yarı yapılandırılmış görüşme formu ile öğrenci görüşleri alınmıştır. Bu tür çalışmalar, naturalistik paradigmaya göre tasarlanan, olgubilim, gömülü teori, etnografi çalışmalarındaki gibi verilerin detaylı incelenmediği ve yorumlanmadığı, sadece görüşme, gözlem, doküman incelemesi gibi veri toplama teknikleri doğrultusunda sosyal olay ve olguların değiştirilmeden ortaya konulduğu betimleme çalışmalarıdır (Z. Arslantürk ve A. Arslantürk, 2013; V. A. Lambert ve C. E. Lambert, 2012; Walker, 2012).

\section{Evren ve Örneklem}

Evren, araştırmadan elde edilen sonuçların genellendiği elemanlar bütününe denir. Araştırmanın evreni büyüdükçe araştırma, değer kazanacağı gibi soyutlaşarak güçleşebilir (Karasar, 1999). Bu araştırma 2018-2019 eğitimöğretim yılında Ağrı merkezde yer alan bir ortaokulda yapılmıştır. Araştırmanın evrenini Ağrı Merkez'de yer alan ortaokullar oluşturmaktadır. Deneysel araştırmayı ortaokulların tamamında gerçekleştirmek mümkünol madığından örneklem seçme yoluna gidilmiştir. Araştırmanın amacına yönelik ihtiyaç duyulan kişilerin, araştırma için evrenden seçilmesine örnekleme denir. Örneklem ise araştırmanın amacına uygun bir şekilde ihtiyaç duyulan verilerin toplanması için bir araştırma evreninden belli yöntemlerle seçilen daha küçük sayıdaki gruba denir. Bu araştırmanın nicel aşamasında seçkisiz örnekleme yöntemlerinden biri olan rasgele örnekleme yöntemi kullanılmıştır. Rastgele örneklem, araştırma için seçilecek kişilerin şansla ya da gelişigüzel seçilmesidir (Akarsu, 2014). Bu kapsamda araştırmanın örneklemini; Ağrı il merkezinde yer alan ve şans yoluyla seçilen bir ortaokulda 5. Sınıf düzeyinde öğrenim gören 88 öğrenci oluşturmaktadır. Nitel aşamada ise amaçlı örnekleme yöntemlerinden ölçüt örnekleme yöntemi kullanılmıştır. Bu örnekleme; araştırmacı tarafından çalışmaya katılacak kişi ve nesnelerin belirlenmesinde belli bir ölçütün getirilmesi söz konusudur. Araştırmacı hangi tür birey veya durumlarla çalışacağına kendisi karar verir ve ölçütünü de kendisi belirler (Büyüköztürk, Kılıç Çakmak, Akgün, Karadeniz ve Demirel, 2016). Çalışmanın nitel aşamasında deney grubuna dâhil edilen ve ters yüz sınıf modeli doğrultusunda eğitim gören 11 öğrenci yer almıştır. Bu öğrenciler deney grubundan rastgele seçilmiştir. 
Tablo 1. Öğrencilerin Sınıflara Göre Dağılımı

\begin{tabular}{cc}
\hline SINIFLAR & ÖĞRENCI SAYISI \\
\hline 5/C -5/B SINIFI (Deney) & 44 \\
5/A- 5/D SINIFI (Kontrol) & 44 \\
\hline
\end{tabular}

Tablo 1'de araştırmaya katılan öğrencilerin deney ve kontrol grubu sayısı gösterilmiştir. Deney grubunu 5/C ve 5/B sinıfları oluştururken kontrol grubunu ise 5/A ve 5/D sınıfları oluşturmaktadır. Çalışmaya katılan öğrencilere ait demografik bilgiler tablo 2 'de sunulmuştur.

Tablo 2 incelendiğinde, kontrol grubunun yarısı erkek yarısı kadın olup deney grubunda kadınların oranı $\% 47,7$, erkeklerin oranı ise $\% 52,3$ 'tür. Yetişilen yer dağılımı incelendiğinde; kontrol grubunda bulunan katılımcıların \%95,5'i şehir merkezi, \%4,5'i ilçede yetişmiş olup deney grubunda şehir merkezinde yetişenlerin oranı $\% 97,7$, ilçede yetişenlerin oran $\% 2,3$ 'tür. Anne eğitim düzeyi incelendiğinde kontrol grubunda annesi okumamış olanların oran $\% 63,6$, ilkokul mezunu olanların oran $\% 27,3$, ortaokul mezunu olanların oranı $\% 9,1$ 'dir. Deney grubunda annesi okumamış olanların oranı $\% 54,5$, ilkokul mezunu olanların oranı \%43,2, ortaokul mezunu olanların oranı $\% 2,3$ 'tür. Baba eğitim durumu incelendiğinde; kontrol grubunda babası okumamış olanların oranı $\% 9,1$, ilkokul mezunu olanların oranı $\% 65,9$, ortaokul veya lise mezunu olanların oranı \%25'tir. Deney grubunda babası okumamış olanların oranı $\% 9,1$, ilkokul mezunu olanların oranı $\% 68,2$, ortaokul veya lise mezunu olanların oranı $\% 22,7^{\prime}$ dir. Her iki gruptaki katılımcıların tamamının annesi ev hanımıdır. Baba meslekleri incelendiğinde; kontrol grubunda babası çalışanların oranı \%95,3, emekli olanların oranı \%2,3, çalışmayanların oranı ise \%2,3'tür. Deney grubunda bulunanların tamamının babası çalışmaktadır.

Tablo 2. Demografik Bilgilerin Gruplara Göre Dağılımı

\begin{tabular}{llcccc}
\hline & & \multicolumn{2}{c}{ Kontrol } & \multicolumn{2}{c}{ Deney } \\
\cline { 3 - 6 } Cinsiyet & $\mathrm{n}$ & $\mathrm{N}$ & $\mathrm{N}$ & $\%$ \\
& Kadın & 22 & $50,0 \%$ & 21 & $47,7 \%$ \\
& Erkek & 22 & $50,0 \%$ & 23 & $52,3 \%$ \\
\hline Yetiştiğiniz & Şehir merkez & 42 & $95,5 \%$ & 43 & $97,7 \%$ \\
yer & İlçe & 2 & $4,5 \%$ & 1 & $2,3 \%$ \\
& Köy & 0 & $0,0 \%$ & 0 & $0,0 \%$ \\
& Diğger & 0 & $0,0 \%$ & 0 & $0,0 \%$ \\
\hline \multirow{2}{*}{ Anne eğitim } & Okumamiş & 28 & $63,6 \%$ & 24 & $54,5 \%$ \\
düzeyi & İlkokul & 12 & $27,3 \%$ & 19 & $43,2 \%$ \\
& Ortaokul & 4 & $9,1 \%$ & 1 & $2,3 \%$
\end{tabular}




\begin{tabular}{|c|c|c|c|c|c|}
\hline \multirow{3}{*}{$\begin{array}{l}\text { Baba eğitim } \\
\text { düzeyi }\end{array}$} & Okumamış & 4 & $9,1 \%$ & 4 & $9,1 \%$ \\
\hline & İlkokul & 29 & $65,9 \%$ & 30 & $68,2 \%$ \\
\hline & Ortaokul-Lise & 11 & $25,0 \%$ & 10 & $22,7 \%$ \\
\hline \multirow[t]{3}{*}{ Baba mesleği } & $\begin{array}{l}\text { Çalışmıyor/ev } \\
\text { hanımı }\end{array}$ & 1 & $2,3 \%$ & 0 & $0,0 \%$ \\
\hline & Çalışıyor & 41 & $95,3 \%$ & 44 & $100,0 \%$ \\
\hline & Emekli & 1 & $2,3 \%$ & 0 & $0,0 \%$ \\
\hline Anne mesleği & $\begin{array}{l}\text { Çalışmıyor/ev } \\
\text { hanımı }\end{array}$ & 44 & $100,0 \%$ & 44 & $100,0 \%$ \\
\hline \multirow{3}{*}{$\begin{array}{l}\text { Aylık gelir } \\
\text { durumu }\end{array}$} & 1600den az & 13 & $29,5 \%$ & 13 & $29,5 \%$ \\
\hline & $1600-3000$ & 28 & $63,6 \%$ & 28 & $63,6 \%$ \\
\hline & $\begin{array}{l}3000 \text { TL ve } \\
\text { üzeri }\end{array}$ & 3 & $6,8 \%$ & 3 & $6,8 \%$ \\
\hline \multirow{3}{*}{$\begin{array}{l}\text { İnternet } \\
\text { kullanımı }\end{array}$} & Hiç & 30 & $68,2 \%$ & 36 & $81,8 \%$ \\
\hline & $\begin{array}{l}\text { kullanmiyoru } \\
\mathrm{m}\end{array}$ & & & & \\
\hline & $0-2$ saat & 14 & $31,8 \%$ & 8 & $18,2 \%$ \\
\hline \multirow{2}{*}{$\begin{array}{l}\text { Sosyal medya } \\
\text { hesabı }\end{array}$} & Var & 4 & $9,1 \%$ & 2 & $4,5 \%$ \\
\hline & Yok & 40 & $90,9 \%$ & 42 & $95,5 \%$ \\
\hline
\end{tabular}

Aylık gelir durumu incelendiğinde; kontrol grubunda geliri 1600 TL'den az olanların oranı \%29,5, 1600-3000 TL geliri olanların oranı \%63,6, $3000 \mathrm{TL}$ ve üzeri geliri olanların oranı $\% 4,5$ 'tir. Kontrol grubunda geliri $1600 \mathrm{TL}$ 'den az olanların oran $\% 29,5,1600-3000$ TL geliri olanların oran $\% 63,6,3000-5000$ TL geliri olanların oranı $\% 4,5$ olup 5000 TL ve üzeri geliri olanların oranı \%2,3'tür. Kontrol grubunda hiç internet kullanmayanların oranı \%68,2, 0-2 saat süre ile kullananların oranı $\% 31,8$ 'dir. Deney grubunda hiç internet kullanmayanların oranı $\% 81,8$ olup $0-2$ saat süre kullananların oranı $\% 18,2$ dir. Sosyal medya hesabı olanların oranı kontrol grubunda $\% 9,1 \mathrm{iken}$, deney grubunda bu oran $\% 4,5$ 'tir.

\section{Veri Toplama Araçları}

$\mathrm{Bu}$ araştırma için gerekli olan veriler 5. sınıf Sosyal Bilgiler dersi Etkin Vatandaşlık öğrenme alanının konularını kapsayan çoktan seçmeli başarı testi ve yarı yapılandırılmış görüşme formu yoluyla toplanmıştır. Katılımcıların öğrenme seviyelerini belirleyen başarı testinin soruları hazırlanırken, Sosyal Bilgiler ders kitabından ve Milli Eğitim bakanlığına ait EBA (Eğitim Bilişim Ağı) adlı sitesinden yararlanılmıştır. Sorular Milli Eğitim Bakanlığına bağlı Eğitim Bilişim Ağı'ndan alındığından dolayı sorularla ilgili tekrardan madde geçerlilik analizleri ve madde ayırt edicilik indeksi gibi 
işlemler yapılmamıştır. Başarı testi çoktan seçmeli olup 24 sorudan oluşmaktadır. Bu sorular Ağrı Merkez'de yer alan bir ortaokulda öğrenim gören 5/A5/D (kontrol), 5/B-5/C (deney) 88 öğrenciye uygulanmıştır. Kullanılan başarı testi ön test ve son test olarak deney ve kontrol gruplarına uygulanmıştır. Öğrencilere uygulanan çoktan seçmeli testin güvenirliği hesaplanmıştır. Çalışmada kullanılan başarı testinin Chronbach alfa katsayısı 0,89 olarak bulunmuştur.

Nitel aşamada kullanılan yarı yapılandırılmış görüşme formunda beş soru yer almıştır. Yarı yapılandırılmış görüşme tekniği, araştırmada amaçlanan konunun netleştirilmesi için araştırmacının hazırlamış olduğu soruları, katılımcılara yönelterek yaptığı görüşmeye denir. Bu görüşmede sorulan sorular esnek, verilen cevaplar ise spesifiktir (Merrıam, çev; Turan, 2015). Araştırmacılar tarafından hazırlanan görüşme formu, alanında uzman olan üç akademisyen tarafından incelenerek güvenirliği test edilmiştir. Yarı yapılandırılmış görüşme, 5 . sınıf öğrencilerinin ters yüz sınıf modeli ile ilgili görüşlerini incelemek amacıyla 11 öğrenci ile yapılmıştır. Araştırmacılar tarafından hazırlanan görüşme formunun ilk halinde 7 soruya yer verilmiştir. Hazırlanan görüşme formu alanda uzman 2'si Sosyal Bilgiler Eğitimi 1'i Eğitim Bilimleri olmak üzere 3 uzmanın görüşüne sunularak soru sayısı 5'e indirilmiştir. Uzman görüşüne sunulan görüşme formunun pilot uygulaması 4 öğrenci ile yapılmıştır. Pilot uygulama sonrasında elde edilen veriler analiz edilerek tekrar uzman görüşüne sunulduktan sonra son şekli verilen görüşme formu 2018-2019 eğitim öğretim yılının güz yarıyılında örnekleme dâhil edilen katılımcılara uygulanmıştır.

\section{Veri Toplama Süreci}

1. Hafta: Araştırmanın yapılacağı deney ve kontrol grupları rastgele seçildi. 5/A ve 5/D kontrol grubu, 5/B ve 5/C ise deney grubu olarak belirlendi. Deney grubunda ki öğrenciler ile görüşme yapıldı. Ters yüz sınıf modeli ile ilgili detaylı açıklamalar yapıldı. Daha sonra hazırlanmış olan ön testler uygulandı. Uygulanmadan önce ön testin bir sınav olarak onları etkilemeyeceği konusunda bilgilendirildiler. Daha sonra velilerinin varsa kendilerinin sosyal medya hesapları, mail adresleri, ulaşılabilecek tüm iletişim bilgileri alındı. Alınan iletişim bilgilerine önceden hazırlanmış olan videolar gönderildi. Bir 
sonraki derse ilk konunun videosu izlenerek gelineceği belirtildi. Konuyla ilgili anlaşılmayan bir şeyin olup olmadığı soruldu ve gerekli dönütler yapıldı. Kontrol grubundaki öğrenciler ile görüşme yapıldı. Kontrol gurubunda ders normal işleyiş sürecine göre yürütüldü. Ters yüz sınıf modeli ile ilgili bir bilgilendirme yapılmadı. Ön test uygulandı.

2. Hafta: Uygulamanın yapılacağı sınıfa gidildi. Derse başlamadan önce öğrencilere, hazırlanan videoyu beğenip beğenmedikleri soruldu. Ders videosunun kısa olması, renkli sunumlar ve bol soru içermesi öğrenciler tarafından beğenilmişti. Konuyu evde herkesin dinleyip dinlemediği soruldu ve hepsi dinlediklerini söylediler. Bunu test etmek için öncelikle konuyla ilgili sorular soruldu ve verdikleri cevaplarla derse hazır geldikleri tespit edildi. Etkin vatandaşlık öğrenme alanının ilk konusu olan "Halka hizmet veren kurumlar" konusu ile ilgili kısa bir özet yapıldı. Sonra tekrar öğrencilerle soru-cevap tekniği uygulanarak konu iyice pekiştirildi. Daha sonra öğrencilere konu ile ilgili etkinlik kâğıtları dağıtıldı. Belli bir süre verildi ve süre bitince etkinlikler birlikte cevapland1. Konuyu iyice pekiştirilmiş oldu.

3. Hafta: Bu hafta "Yaşadığım yerin yönetimi" konusu işlendi. Konu ile ilgili videolar hakkında öğrenciler ile görüşüldü. Derste birkaçöğrenci kaldırılarak videolarda bu haftanın konusu ile ilgili ne anlatıldığı neler yapıldığı soruldu ve öğrenciler soruları cevapladılar. Konu anlatılırken video esnasında öğrencilerden videodaki sunumları not almaları gerektiği söylenmişti ve sınıf içerisinde bu notlar kontrol edildi. Böylece öğrenme esnasında rehberden tamamen bağımsız olmadıkları, sürekli kontrol edildikleri hissettirildi. Konu ile ilgili kısa bir özet yapıldı. Sonra önceden hazırlanmış etkinlik kâğıtları dağıtıldı ve sonra ders bitirildi.

4. Hafta: Bu hafta "Temel haklarımızı öğrenelim" konusu işlendi. Konu ile ilgili bilgi vermeden önce öğrencilere konuyla ilgili sorular yöneltildi:

- En temel hakkımız hangisidir?

- Devlet hangi durumlarda hak ve özgürlüklerimizi kısmen ya da tamamen durdurabilir?

- Kaç yaşını dolduran bireyler ülke yönetimine katılabilir?

$\mathrm{Bu}$ vb. gibi sorular yöneltilerek konuya hazırlıklı gelip gelmediklerine bakılmıştır. Daha sonra konu ile ilgili kısa bir özet yapıldı. Sonra bireyin sahip 
olması gereken haklar üzerine konuşuldu. Sonra bu hakları tahtaya yazmaları için öğrenciler rastgele seçildi ve sahip olduğumuz haklar tahtaya yazılmış oldu. Böylece öğrenciler hakları konusunda bilinçlendirildi. Bu ders daha çok soru-cevap ağırlıklı bir ders oldu. Daha sonra öğrencilere etkinlik kâğıtları dağıtıldı ve etkinlik yapılarak ders iyice pekiştirildi. Bu hafta daha önce derse hiç ilgisi olmayan öğrencilerin de derse aktif bir şekilde katıldıkları görüldü.

5. Hafta: Bu hafta "Bayrağımız ve istiklal marşımız" konusu işlendi. Konuya başlamadan önce beyin firtınası yapıldı. Video hakkında konuşuldu ve sonra konu ile ilgili kısa bir özet yapıldı. Daha sonra milli değerlerimiz üzerine konuşuldu. Konuşma bittikten sonra öğrencilere boş kağıt dağıtıldı. Tahtaya bayrak çizilerek öğrencilere nasıl çizileceği hakkında bilgilendirme yapıldı ve daha sonra dağıtılan kağıtlara bayrak çizilmesi istendi. Bayrağın çizimi esnasında öğrencilerin dersten aldığı keyif görüldü. Konu iyice pekiştirilsin diye önceden hazırlanan etkinlik kağıtları dağıtıldı ve cevaplandı.

6. Hafta: Bu hafta kontrol ve deney grupları ile görüşüldü. Deney gruplarında öğrenciler ile sürdürülen uygulamanın sonuna gelindi. Öğrencilerin uygulamanın devam etmesini istemeleri, modelin etkili olduğunu göstermektedir. Daha sonra hem kontrol hem deney gruplarına son test akademik başarı testi uygulanmıştır.

7. Hafta: Bu hafta deney grubunun oluşturan 11 öğrenci ile yarı yapılandırılmış görüşme yapılmıştır. Görüşme soruları araştırmacı tarafindan önceden hazırlanmıştır. Görüşme soruları ters yüz sınıf modelinin etkililiği hakkındadır. Görüşme bittikten sonra görüşme formları toplanarak veriler analiz edilmiştir

\section{Verilerin Analizi}

Araştırmanın nitel aşamasında elde edilen verilerin analizinde betimsel analiz yöntemi kullanılmıştır. Verilerin ayrıntıya inmeden araştırmacı tarafından yorumlanmasına betimsel analiz denir (Sönmez ve Alacapınar, 2014). Nicel araştırma sonucu elde edilen verilerin analizinde istatistik paket programı kullanılmıştır. Verilerin ön test ve son test puanlarının normal dağılıp 
dağılmadığının belirlenmesi amacıyla çarpıklık ve basıklık katsayıları incelenmiştir. Çarpıklık ve basıklık değerleri Tablo 3' te sunulmuştur.

Tablo 3. Çarpıklık basıklık katsayıları

\begin{tabular}{lcc}
\hline & Ön test & Son test \\
\hline Çarpıklık & 0,652 & 0,458 \\
\hline Çapıklık Std. Hatası & 0,121 & 0,228 \\
\hline Basıklık & 0,221 & 0,414 \\
\hline Basıklık Std.Hatası & 0,325 & 0,329 \\
\hline
\end{tabular}

Tablo 3 incelendiğinde, çarpıklık basıklık katsayılarının -1;1 aralığında (Büyüköztürk, Kılıç Çakmak, Akgün, Karadeniz ve Demirel, 2016). olması verilerin normal dağılıma uygunluk gösterdiğini ifade etmektedir. Veriler normal dağılım gösterdiği için veriler analiz edilirken, iki grup ortalaması arasında belirgin bir farkın olup olmadığını belirlemek için $\mathrm{t}$ testi, üç ve daha fazla bağımsız ortalama arasındaki farkın hesaplanmasında tek yönlü varyans analizi (Anova), ortaya çıkan farkın hangi gruplar lehine olduğunu belirlemek için ise Tukey testi kullanılmıştır.

\section{Bulgular ve Yorum}

Araştırmanın sayılan ana ve alt problemlerine ilişkin veriler, uygulanan Sosyal Bilgiler başarı ön testi ile başarı son testi ve yarı yapılandırılmış görüşme formundan elde edilmiştir. Araştırmanin ana problemi doğrultusunda cevabı aranan alt problemlere ait bulgulara sırasıyla yer verilmiştir.

\section{Birinci Alt Probleme İlişkin Bulgular}

Kontrol ve deney gruplarının ön test ve son test ortalamaları arasında anlamlı bir fark olup olmadığına ilişkin problem bulguları incelenmiştir. Ön test ve son test skorlarının kontrol ve deney grubu ortalamaları ve bu ortalamalar arasındaki farkın anlamlı olup olmadığının tespiti için yapılan tek yönlü varyans analizi yapılmıştır. Sonuçlar Tablo 4'te sunulmuştur. 
Tablo 4. Gruplara göre ön test son test ortalamaları arasındaki farka ait tek yönlü varyans analizi sonuçlan

\begin{tabular}{lllcccc}
\hline Grup & $\mathbf{N}$ & Ortalama & $\begin{array}{c}\text { Std. } \\
\text { Sapma }\end{array}$ & $\mathbf{t}$ & $\mathbf{P}$ \\
\hline Ön test & Kontrol & 44 & 54,7 & 15,4 & 0,81 & 0,420 \\
& Deney & 44 & 51,7 & 19,1 & & \\
\hline Son test & Kontrol & 44 & 58,2 & 16,5 & $-1,45$ & $0,038^{*}$ \\
& Deney & 44 & 63,7 & 19,1 & & \\
\hline
\end{tabular}

${ }^{*} \mathrm{p}>0,05$

Tablo 4 incelendiğinde ön test skorları kontrol ve deney grupları arasında anlamlı düzeyde farklılık göstermezken $(\mathrm{p}>0,05)$, son test skoru kontrol ve deney grupları arasında anlamlı düzeyde farklılık göstermektedir. Deney grubunun son test skoru kontrol grubundan anlamlı derecede daha yüksektir.

\section{İkinci Alt Probleme İlişkin Bulgular}

Kontrol ve deney gruplarının ön test ve son test puanları arasında anlamlı bir fark olup olmadığına ilişkin bulgular incelenmiştir. Çalışma gruplarında ön test ve son test ortalamaları ve bu ortalamalar arasındaki farkın anlamlı olup olmadığının tespiti için yapılan bağımlı gruplarda t testi karşılaştırması yapilmıştır. Sonuçlar Tablo 5'te sunulmuştur.

Tablo 5. Deney ve kontrol grupların öntest son test başarı puanları arasındaki farka ait t-testi sonuçları

\begin{tabular}{llccccc}
\hline Grup & N & Ortalama & $\begin{array}{c}\text { Std. } \\
\text { Sapma }\end{array}$ & T & P \\
\hline Kontrol & Ön test & 44 & 54,73 & 15,42 & $-2,368$ & $0,022^{*}$ \\
& Son test & 44 & 58,20 & 16,46 & & \\
\hline Deney & Ön test & 44 & 51,73 & 19,10 & $-2,834$ & $0,000^{*}$ \\
& Son test & 44 & 63,68 & 19,10 & & \\
\hline
\end{tabular}

${ }^{*} \mathrm{p}<0,05$

Tablo 5 incelendiğinde, kontrol ve deney gruplarında ön test ve son test ortalamaları arasında anlamlı fark bulunmakta olup her iki grupta da son test ortalaması ön test ortalamasından anlamlı derecede daha büyüktür. 


\section{Üçüncü Alt Probleme İlişkin Bulgular}

Kontrol ve deney grubunda bulunan öğrencilerin cinsiyet özellikleri ile ön test ve son test başarı puanları arasında anlamlı fark olup olmadığına ilişkin bulgular incelenmiştir. Deney ve kontrol gruplarında ön test ve son test puanlarının cinsiyete göre ortalamaları ve bu ortalamalar arasındaki farkın anlamlı olup olmadığının tespiti için yapılan bağımsız gruplarda t testi karşılaştırılması yapılmıştır. Sonuçlar Tablo 6'da sunulmuştur.

Tablo 6 incelendiğinde, bağımsız gruplarda t testi sonuçları, kontrol ve deney grubunda ön test ve son test skorları cinsiyete göre anlamlı düzeyde fark göstermemektedir $(p>0,05)$. Diğer bir ifade ile kadın ve erkeklerin ön test ve son test skorları çalışma gruplarının ikisinde de aynı düzeydedir.

Tablo 6. Cinsiyete göre deney ve kontrol grubu öğrencilerinin ön test ve son test başarn puanları arasındaki farka ait t-testi Sonuçları

\begin{tabular}{lllccccc}
\hline Grup & & & $\mathbf{N}$ & Ortalama & Std. Sapma & $\mathbf{t}$ & $\mathbf{P}$ \\
\hline Kontrol & Ön test & Kadın & 22 & 58,7 & 15,5 & 1,762 & 0,085 \\
& & Erkek & 22 & 50,7 & 14,6 & & \\
\cline { 2 - 9 } & Son test & Kadın & 22 & 60,2 & 16,3 & 0,802 & 0,427 \\
& & Erkek & 22 & 56,2 & 16,7 & & \\
\hline \multirow{2}{*}{ Deney } & Ön test & Kadın & 21 & 52,2 & 17,4 & 0,152 & 0,880 \\
& & Erkek & 23 & 51,3 & 20,9 & & \\
\cline { 2 - 8 } & Son test & Kadın & 21 & 63,5 & 17,4 & $-0,52$ & 0,959 \\
& & Erkek & 23 & 63,8 & 20,9 & & \\
\hline
\end{tabular}

${ }^{*} \mathrm{p}<0,05$

\section{Dördüncü Alt Probleme İlişkin Bulgular}

Kontrol ve deney gruplarında bulunan öğrencilerin gelir durumları ile ön test ve son test başarı puanları arasında anlamlı farkın olup olmadığına ilişkin bulgular incelenmiştir. Deney ve kontrol gruplarında ön test ve son test puanlarının gelire göre ortalamaları ve bu ortalamalar arasındaki farkın anlamlı olup olmadığının tespiti için yapılan tek yönlü varyans analizi yapılmıştır. Sonuçlar Tablo 7'de sunulmuştur. 
Tablo 7. Gelir düzeyine göre deney ve kontrol grubu öğrencilerinin ön test ve son test başarı puanları arasındaki farka ait tek yönlü varyans analizis sonuçları

\begin{tabular}{|c|c|c|c|c|c|c|c|}
\hline Grup & & & $\mathbf{N}$ & Ortalama & Std. Sapma & $F$ & $\mathbf{P}$ \\
\hline \multirow[t]{8}{*}{ Kontrol } & Ön test & 1600den az & 13 & 56,6 & 15,2 & 1,047 & 0,360 \\
\hline & & $1600-3000$ & 28 & 52,7 & 16,0 & & \\
\hline & & $3000+$ & 3 & 65,3 & 6,1 & & \\
\hline & & Total & 44 & 54,7 & 15,4 & & \\
\hline & Son Test & 1600den az & 13 & 60,6 & 17,8 & 1,340 & 0,273 \\
\hline & & $1600-3000$ & 28 & 55,7 & 16,2 & & \\
\hline & & $3000+$ & 3 & 70,7 & 2,30 & & \\
\hline & & Total & 44 & 58,2 & 16,9 & & \\
\hline \multirow[t]{8}{*}{ Deney } & Ön test & 1600den az & 13 & 49,85 & 20,696 & 0,101 & 0,904 \\
\hline & & $1600-3000$ & 28 & 52,71 & 19,385 & & \\
\hline & & $3000+$ & 3 & 50,67 & 12,858 & & \\
\hline & & Total & 44 & 51,73 & 19,104 & & \\
\hline & Son Test & 1600den az & 13 & 63,2 & 18,90 & 0,070 & 0,932 \\
\hline & & $1600-3000$ & 28 & 64,3 & 19,41 & & \\
\hline & & $3000+$ & 3 & 60,0 & 24,33 & & \\
\hline & & Total & 44 & 63,7 & 19,10 & & \\
\hline
\end{tabular}

$\overline{{ }^{*} \mathrm{p}>0,05}$

Tablo 7 incelendiğinde, tek yönlü varyans analizi sonuçları kontrol ve deney grubunda ön test ve son test skorları gelire göre anlamlı düzeyde fark göstermemektedir ( $p>0,05)$. Diğer bir ifade ile farklı gelir düzeyine sahip kişilerin ön test ve son test skorları çalışma gruplarının ikisinde de aynı düzeydedir.

\section{Beşinci Alt Probleme İlişkin Bulgular}

Kontrol ve deney gruplarında bulunan öğrencilerin internet kullanma durumları ile ön test ve son test başarı puanları arasında anlamlı bir fark olup olmadığına ilişkin bulgular incelenmiştir. Deney ve kontrol gruplarında ön test ve son test puanlarının internet kullanma düzeylerine göre ortalamaları ve bu ortalamalar arasındaki farkın anlamlı olup olmadığının tespiti için yapılan bağımsız gruplarda $t$ testi karşılaştırılması yapılmıştır. Sonuçlar Tablo 8 ' de sunulmuştur. 
Tablo 8. Internet kullanma durumuna göre deney ve kontrol grubu öğrencilerinin ön test ve son test başarı puanları arasındaki farka ait $t$-testi sonuçları

\begin{tabular}{lllccccc}
\hline Grup & & N & Ortalama & Std. Sapma & T & P \\
\hline Kontrol & Ön test & Hiç kullanmiyorum & 30 & 57,5 & 15,6 & 1,766 & 0,085 \\
& & $0-2$ saat & 14 & 48,9 & 13,7 & & \\
\cline { 2 - 8 } & Son & Hiç kullanmiyorum & 30 & 59,3 & 16,1 & 0,372 & 0,711 \\
& test & 0-2 saat & 14 & 55,7 & 17,4 & & \\
\hline \multirow{2}{*}{ Deney } & Ön test & Hiç kullanmiyorum & 36 & 50,7 & 18,5 & $-0,778$ & 0,441 \\
& & 0-2 saat & 8 & 56,5 & 22,4 & & \\
\cline { 2 - 8 } & Son & Hiç kullanmiyorum & 36 & 60,5 & 18,3 & $-2,480$ & $0,017^{*}$ \\
& test & 0-2 saat & 8 & 78,0 & 16,9 & & \\
\hline
\end{tabular}

${ }^{*} \mathrm{p}<0,05$

Tablo 8 incelendiğinde, bağımsız gruplarda $t$ testi sonuçları kontrol grubunda ön test ve son test skorları internet kullanma düzeyine göre anlamlı düzeyde fark göstermemektedir. Deney grubunda ön test ortalaması internet kullanma düzeyine göre anlamlı fark göstermezken, son test ortalaması internet kullanma düzeyine göre anlamlı fark göstermektedir. 0-2 saat internet kullananların son test ortalaması hiç kullanmayanlardan anlamlı derecede daha yüksektir.

\section{Altıncı Alt Probleme İlişkin Bulgular}

Kontrol ve deney gruplarında bulunan öğrencilerin yerleşim yeri durumları ile ön test ve son test başarı puanları arasında anlamlı bir fark olup olmadığına ilişkin bulgular incelenmiştir. Deney ve kontrol gruplarında ön test ve son test puanlarının yaşanılan yere göre ortalamaları ve bu ortalamalar arasındaki farkın anlamlı olup olmadığının tespiti için yapılan bağımsız gruplarda t testi karşılaştırılması yapılmıştır. Sonuçlar Tablo 9' da sunulmuştur.

Tablo 9. Yaşanılan yerleşim yerine göre deney ve kontrol grubu öğrencilerinin ön test ve son test başarı puanları arasındaki farka ait t-testi sonuçları

\begin{tabular}{lllccccc}
\hline Grup & & & $\mathbf{N}$ & Ortalama & Std. Sapma & $\mathbf{T}$ & $\mathbf{P}$ \\
\hline Kont- & Ön & Şehir merkez & 42 & 54,4 & 15,7 & $-0,678$ & 0,501 \\
rol & test & İlçe & 2 & 62,0 & 2,8 & & \\
\cline { 2 - 7 } & Son & Şehir merkez & 42 & 57,5 & 16,5 & $-5,663$ & $0,000^{*}$ \\
& test & İlçe & 2 & 72,0 & 0,0 & & \\
\hline \multirow{2}{*}{ Deney } & Ön & Şehir merkez & 43 & 51,7 & 19,3 & $-0,014$ & 0,989 \\
& test & İçe & 1 & 52,0 & - & & \\
\cline { 2 - 7 } & Son & Şehir merkez & 43 & 63,1 & 21,4 & $-1,298$ & 0,201 \\
& test & İçe & 1 & 88,0 & & & \\
\hline
\end{tabular}

${ }^{*} \mathrm{p}<0,05$ 
Tablo 9 incelendiğinde bağımsız gruplarda t testi sonuçları, kontrol grubunda son test ortalaması yaşanılan yere göre anlamlı düzeyde fark göstermekte olup ilçelerde yaşayanların son test ortalaması şehir merkezinde yaşayanlardan anlamlı derecede daha yüksektir. Kontrol grubunda ön test ortalaması ise yaşanılan yere göre anlamlı fark göstermemektedir. Deney grubunda ön test ve son test skorları yaşanılan yere göre anlamlı düzeyde fark göstermemektedir $(p>0,05)$. Diğer bir ifade ile şehir merkezi ve ilçede yaşayanların ön test ve son test skorları deney grubunda aynı düzeydedir.

\section{Yedinci Alt Probleme İlişkin Bulgular}

Kontrol ve deney gruplarında bulunan öğrencilerin anne eğitim düzeyleri ile ön test ve son test başarı puanları arasında anlamlı bir fark olup olmadığına ilişkin bulgular incelenmiştir. Deney ve kontrol gruplarında ön test ve son test puanlarının anne eğitim düzeyine göre ortalamaları ve bu ortalamalar arasındaki farkın anlamlı olup olmadığının tespiti için yapılan tek yönlü varyans analizi yapılmıştır. Sonuçları Tablo 10'da sunulmuştur.

Tablo 10. Anne eğitim düzeyine göre deney ve kontrol grubu öğrencilerinin ön test ve son test başarı puanları arasındaki farka ait tek yönlü varyans analizi sonuçları

\begin{tabular}{|c|c|c|c|c|c|c|c|}
\hline Grup & & & $\mathbf{N}$ & Ortalama & Std. Sapma & $\mathbf{F}$ & $\mathbf{P}$ \\
\hline \multirow[t]{8}{*}{ Kontrol } & Ön test & Okumamış & 28 & 59,6 & 16,2 & 4,684 & $0,015^{*}$ \\
\hline & & İlkokul & 12 & 47,7 & 10,4 & & \\
\hline & & Ortaokul & 4 & 42,0 & 4,0 & & \\
\hline & & Total & 44 & 54,7 & 15,4 & & \\
\hline & Son test & Okumamış & 28 & 64,3 & 16,0 & 6,898 & $0,003^{*}$ \\
\hline & & İlkokul & 12 & 48,7 & 11,4 & & \\
\hline & & Ortaokul & 4 & 44,0 & 9,8 & & \\
\hline & & Total & 44 & 58,2 & 16,5 & & \\
\hline \multirow[t]{6}{*}{ Deney } & Ön test & Okumamış & 24 & 55,00 & 17,022 & 2,020 & 0,163 \\
\hline & & İlkokul & 19 & 46,74 & 21,126 & & \\
\hline & & Total & 43 & 51,35 & 19,162 & & \\
\hline & Son test & Okumamış & 24 & 66,7 & 19,1 & 1,949 & 0,170 \\
\hline & & İlkokul & 19 & 58,6 & 18,3 & & \\
\hline & & Total & 43 & 63,1 & 18,9 & & \\
\hline
\end{tabular}

${ }^{*} \mathrm{p}<0,05$

Tablo 10 incelendiğinde tek yönlü varyans analizi sonuçları, kontrol grubunda ön test ve son test skorları anne eğitim düzeyine göre anlamlı fark gös- 
terirken $(\mathrm{p}<0,05)$, deney grubunda ön test ve son test skorları anne eğitim düzeyine göre anlamlı fark göstermemektedir ( $p>0,05)$. Farklılığın hangi gruptan kaynaklandığını tespit etmek amacıyla yapılan TUKEY testi sonuçlarına göre; kontrol grubunda; ön test ve son test için; annesi okumayanların ortalaması annesi ilkokul mezunu olanlardan, annesi ilkokul mezunu olanların ortalaması da annesi ortaokul mezunu olanlardan anlamlı derecede daha yüksektir.

\section{Sekizinci Alt Probleme İlişkin Bulgular}

Kontrol ve deney gruplarında bulunan öğrencilerin baba eğitim düzeyleri ile ön test ve son test başarı puanları arasında anlamlı bir fark olup olmadığına ilişkin bulgular incelenmiştir. Deney ve kontrol gruplarında ön test ve son test puanlarının baba eğitim düzeyine göre ortalamaları ve bu ortalamalar arasındaki farkın anlamlı olup olmadığının tespiti için yapılan tek yönlü varyans analizi yapılmıştır. Sonuçlar Tablo 11' de sunulmuştur.

Tablo 11. Baba eğitim düzeyine göre deney ve kontrol grubu öğrencilerinin ön test ve son test başarı puanları arasındaki farka ait tek yönlü varyans analizi sonuçları

\begin{tabular}{|c|c|c|c|c|c|c|c|}
\hline Grup & & & $\mathbf{N}$ & Ortalama & Std. Sapma & $\mathbf{F}$ & $\mathbf{P}$ \\
\hline \multirow[t]{10}{*}{ Kontrol } & \multirow[t]{5}{*}{ Ön Test } & Okumamış & 4 & 53,0 & 20,8 & \multirow[t]{5}{*}{0,617} & \multirow[t]{5}{*}{0,608} \\
\hline & & İlkokul & 29 & 53,8 & 14,6 & & \\
\hline & & Ortaokul & 5 & 52,0 & 14,4 & & \\
\hline & & Lise & 6 & 62,7 & 18,4 & & \\
\hline & & Total & 44 & 54,7 & 15,4 & & \\
\hline & \multirow[t]{5}{*}{ Son Test } & Okumamış & 4 & 54,5 & 15,8 & \multirow[t]{5}{*}{0,378} & \multirow[t]{5}{*}{0,769} \\
\hline & & İlkokul & 29 & 59,2 & 17,2 & & \\
\hline & & Ortaokul & 5 & 52,0 & 14,9 & & \\
\hline & & Lise & 6 & 61,0 & 16,8 & & \\
\hline & & Total & 44 & 58,2 & 16,4 & & \\
\hline \multirow[t]{10}{*}{ Deney } & \multirow[t]{5}{*}{ Ön Test } & Okumamış & 4 & 57,0 & 23,2 & \multirow[t]{5}{*}{0,581} & \multirow[t]{5}{*}{0,631} \\
\hline & & İlkokul & 30 & 52,4 & 18,9 & & \\
\hline & & Ortaokul & 5 & 53,6 & 19,5 & & \\
\hline & & Lise & 5 & 41,6 & 19,7 & & \\
\hline & & Total & 44 & 51,7 & 19,1 & & \\
\hline & \multirow[t]{5}{*}{ Son Test } & Okumamış & 4 & 69,0 & 20,7 & \multirow[t]{5}{*}{0,798} & \multirow[t]{5}{*}{0,502} \\
\hline & & İlkokul & 30 & 62,5 & 18,9 & & \\
\hline & & Ortaokul & 5 & 73,6 & 18,0 & & \\
\hline & & Lise & 5 & 56,8 & 21,0 & & \\
\hline & & Total & 44 & 63,7 & 19,1 & & \\
\hline
\end{tabular}

${ }^{*} \mathrm{p}<0,05$ 
Tablo 11 incelendiğinde tek yönlü varyans analizi sonuçlarına göre, deney ve kontrol grubunda ön test ve son test skorları baba eğitim düzeyine göre anlamlı fark göstermemektedir $(p>0,05)$. Diğer bir ifade ile babası farklı eğitim düzeyine sahip kişilerin ön test ve son test skorları deney ve kontrol grubunda aynı düzeydedir denilebilir.

\section{Dokuzuncu Alt Probleme İlişkin Bulgular}

Deney grubu ile yapılan görüşme sonucunda katılımcıların ters yüz sınıf modeli ile ilgili önerilerine ait bulgular incelenmiştir. Ters yüz sınıf modeli ile ilgili önerileriniz nelerdir? Sorusuna yönelik görüşler incelenmiştir. Sonuçlar Tablo 12'de sunulmuştur.

Tablo 12. Katılımcıların ters-yüz sınıf modeli ile ilgili önerilerine ilişkin sonuçlar

\begin{tabular}{lcc}
\hline Ters yüz sınıf modeli ile ilgili öneriler & Frekans (f) & Yüzde (\%) \\
\hline Ortam & 7 & 31,85 \\
Tablet dağıtımı & 6 & 27,2 \\
Bilişim sınıfı & 4 & 18,2 \\
Video içeriklerinin düzenlenmesi & 3 & 13,65 \\
Müfredat & 2 & 9,1 \\
\hline Toplam & $\mathbf{2 2}$ & $\mathbf{1 0 0}$ \\
\hline
\end{tabular}

Tablo 12'ye göre katılımcıların çoğu, ters yüz sınıf modeli ile ilgili ortam yetersizliği ve tablet dağıtımı ile ilgili önerilerini sunmuşlardır. Tablo 12 'de öğrencilerin \%31,85'i (7) video izleyebilecek ortamın sağlanmasını, \%27,2'si (6) ise okullarda tablet dağıtılmasını önermiştir. \%18,2'si (4) okuldan sonra bilişim sınıflarının açılmasına izin verilmesini \% 13,65'i (3) video içerisinde bazı düzenlemelerin yapılmasını, \% 9,1'i (2) ise bu modelin müfredatta yer almasını önermişlerdir. Bu konuda bazı öğrenci görüşlerine yer vermek gerekirse;

- Ö1: "Videoları izleyebileceğimiz ortam sağlanmalı ve okul müdürü tarafından öğrencilere tablet dağıtılmalıdır".

- Ö2: "Tüm derslerimize uygulanmalıdır".

- Ö3: "Bilişim sımıları bizim için açık olsa daha iyi olur".

- Ö4: "Videodaki slaytların çıktısı verilebilirdi ve videolarda daha çok resim olabilirdi". 
- Ö5: "Bu modelde zorluk çekmemek için teknolojik araçlar dă̆ıtılmalı ya da bilgisayar sımıfları dersten sonra açılmalıdır". şeklinde görüş belirtmiştir.

Katılımcların görüşleri incelendiğinde genel olarak, ters yüz sınıf modeline uygun ortamların seçilmesi, uygulamanın yapılacağı araçların temin edilmesi ve amaca uygun olarak öğretim programının düzenlenmesi gibi önerilerde bulundukları görülmüştür.

\section{Onuncu Alt Probleme İlişkin Bulgular}

Araştırmaya katılanların etkin vatandaşlık öğrenme alanının, ters yüz sınıf modeline göre işlenmesinin derse olan ilgiyi arttırıp arttırmadığına ilişkin görüşleri incelenmiştir. Sonuçlar Tablo 13' te sunulmuştur.

Tablo 13. Katılımcıların etkin vatandaşlık öğrenme alanının, ters yüz sını modeline göre işlenmesinin derse olan ilgiyi arttırı arttırmadığına ilişkin görüşlerine ait sonuçlar

\begin{tabular}{lcc}
\hline Ters yüz sınıf modelinin derse karşı ilgiye katkısı & Frekans (f) & Yüzde (\%) \\
\hline Çok etkinlik & 4 & 20 \\
İlk oluşu & 10 & 50 \\
Beğenmek & 6 & 30 \\
\hline Toplam & $\mathbf{2 0}$ & $\mathbf{1 0 0}$ \\
\hline
\end{tabular}

Tablo 13'e göre katılımcların \%20'si (4) ilgi kavramını, çok etkinlik olarak değerlendirmiştir. Bu değerlendirmenin nedeni sorulduğunda ise sınıf içerisinde çok etkinliğin yapılmasının derse olan ilgiyi artırdığını, \% 50'si (10) modelin ilk defa kullanılmasının, derse olan ilgiyi artırdığını, \%30'u (6) modelin beğenilmesinin derse olan ilgilerini artırdığını dile getirmiştir. Bu konuda bazı öğrenci görüşlerinden örnek vermek gerekirse;

- Ö1: "Evet arttırdı. Çünkü öğretmenimiz çok etkinlik yaptırdı. Hem de ilk defa videodan ders işledim. Çok güzeldi. Öğretmenimiz bizi yoğun çalı̧tırdı". Sosyal Bilgiler dersini sevdim. Çünkü istediğimde videoyu tekrar izleyebildim.

- Ö2: "Evet arttırdl. Çünkü ilk defa evde ders dinliyorduk, okulda ödev yapıyorduk ve çok heyecanlıdım bu da derse olan ilgimi arttırdı".

- Ö3: "Evet arttırdr. Çünkü yeni model dikkatimi çekti". şeklinde görüş belirtmiştir. 
Katılımcıların etkin vatandaşlık öğrenme alanının, ters yüz sınıf modeline göre işlenmesinin, derse olan ilgiyi arttırıp arttırmadığına ilişkin görüşleri incelendiğinde, modelin daha önce kullanılmamış olması ve böyle bir modelle ilk defa ders işlenmesinin katılımcıların derse karşı ilgilerini arttırdığı sonucuna ulaşılmıştır.

\section{On Birinci Alt Probleme İlişkin Bulgular}

Katılımcıların izlemiş oldukları videoların faydalı olup olmadığı ile ilgili görüşleri incelenmiştir. Sonuçlar Tablo 14' te sunulmuştur.

Tablo 14. Katılımcıların izlemiş oldukları videolarn faydalı olup olmadı̆̆ı ile ilgili görüşlerine ait sonuçlar

\begin{tabular}{lcc}
\hline Videoların faydalılı̆̆ & Frekans (f) & Yüzde (\%) \\
\hline Video içeriği & 8 & 42,08 \\
Zaman & 7 & 36,82 \\
Görüntü-ses & 2 & 10,55 \\
Tekrar & 2 & 10,55 \\
\hline Toplam & $\mathbf{1 9}$ & $\mathbf{1 0 0}$ \\
\hline
\end{tabular}

Tablo 14'e göre katılımcıların \% 42,08'si (8) faydalılık kavramına video içeriği, \% 36,82' si (7) zaman olarak, \% 10,55'i (2) öğretmeninin görüntü ve sesinin olması, \% 10,55'i (2) ise videoların istenildiği zaman tekrar edilmesi ile ifade ettikleri görülmektedir. Bu konuda bazı öğrenci görüşlerinden örnek vermek gerekirse;

- Ö1:" Evet düşünüyorum. Çünkü videolardaki anlatılan şeyleri unutsam bile videoları açıp tekrar izleyebiliyordum. Videolar çok güzel hazırlanmıştı. İstediğim zaman durdurup açabildim".

- Ö2: "Evet faydalıydı. Videoda öğretmenimizi de görüyorduk. Sesini duyuyorduk. Sinıfta gibi hissettim. Renkli videolarm olması ve videolara her yerde ulaşmamı güzeldi".

- Ö3: "Evet düşünüyorum. Çünkü videolarnn içeriği güzeldi. Bir sürü test vardl. Slaytlar renkliydi. İstediğim zaman tekrar tekrar dinleyebildim". şeklinde görüş belirtmiştir. 
Katılımcıların izlemiş oldukları videoların faydalı olup olmadığı ile ilgili görüşleri incelendiğinde, video içeriklerinin istenilen kalitede olması ve videolar sayesinde sürekli ders tekrarının yapılması, hazırlanan videoların faydalı olduğuna dair görüşlerde bulundukları tespit edilmiştir.

\section{On İkinci Alt Probleme İlişkin Bulgular}

Katılımcıların evde yapılan etkinliklerin, öğretmen kontrolünde sınıf içerisinde yapılmasının, konunun kalıcılığını sağlayıp sağlamadığına ilişkin görüşleri incelenmiştir. Sonuçlar Tablo $15^{\prime}$ te sunulmuştur.

Tablo 15. Katılımcıların evde yapılan etkinliklerin, öğretmen kontrolünde sınıf içerisinde yapılmasının, konunun kalıcılığını sağlayıp să̆lamadığına ilişkin görüşlerine ait sonuçlar

\begin{tabular}{lcc}
\hline Etkinliklerin öğretmen kontrolünde yapılmasının faydası & Frekans (f) & Yüzde (\%) \\
\hline Soru sormak & 9 & 64,30 \\
Etkinlik & 5 & 35,30 \\
\hline Toplam & $\mathbf{1 4}$ & $\mathbf{1 0 0}$ \\
\hline
\end{tabular}

Tablo 15'e göre katılımcların \% 64,30'u (9) kalıcılık kavramını, öğretmene soru sormak, \% 35,30'u (5) ise etkinlik olarak cevaplamıştır. Katılımcilar bunun gerekçesi olarak sınıf içinde öğretmen kontrolünde etkinlik yapılmasının daha kalıcı öğrenmeler gerçekleştirdiğini ifade etmiştir. Bu konuda bazı öğrenci görüşlerine yer vermek gerekirse;

- Ö1: “Evet. Çünkü evde ödev yaptığımda anlamadı̆̆ım konuları soramıyordum. Aileme soruyordum onlarda bazen bilmiyorlardl. Ama simfta hemen öğretmene sorabiliyordum. Sinıf içerisinde çok etkinlik yaptık".

- Ö2: "Evet sağladı. Çünkü hocamız bize oyunlar oynatıyordu. Öğretmenimiz bize sorular sordu, etkinlik yaptırd. Evde yapamadığımı sorular okula gittiğimizde hocamiza sorabiliyorduk".

şeklinde görüş belirtmiştir.

Katılımcların evde yapılan etkinliklerin, öğretmen kontrolünde sınıf içerisinde yapılmasının, konunun kalıcılığını sağlayıp sağlamadığına ilişkin görüşlerine bakıldığında genel olarak, sınıf içinde etkinlik yapabilmenin ve sınıf içinde ödevler yapılırken öğretmene soru sorabilmenin konunun kalıcılığını sağladığı yönündeki görüşleri ön plana çıkmıştır. 


\section{On Üçüncü Alt Probleme İlişkin Bulgular}

Araştırmaya katılanların ters yüz sınıf modelinin olumlu ve olumsuz yönleri ile ilgili görüşleri incelenmiştir. Sonuçlar Tablo 16'da sunulmuştur.

Tablo 16. Katılımcıların ters yüz sını modelinin olumlu ve olumsuz yönleri ile ilgili görüşlerine ait sonuçlar

\begin{tabular}{lcc}
\hline Ters yüz sınıf modelinin olumlu ve olumsuz & Frekans (f) & Yüzde (\%) \\
yönleri & & \\
\hline Araç yetersizliği & 5 & 35,72 \\
Yer & 2 & 14,30 \\
Videoların süresi & 3 & 21,42 \\
Öğretmen rolü & 4 & 28,56 \\
\hline Toplam & $\mathbf{2 2}$ & $\mathbf{1 0 0}$ \\
\hline
\end{tabular}

Tablo 16'ya göre katılımcıların \%35,72'si (5) olumsuz olarak teknolojik araçların olmayışını ve \%14,30'u (2) istenilen her yerde videolara erişilmesini, \%21,42'si (3) videoların kısa oluşunu, \%28,56's1 (4) öğretmenlerin rolünü olumlu olarak cevaplandırmıştır. Bu konuda bazı öğrencilerin görüşlerinden örnek vermek gerekirse;

- Ö1: "Tabletim, bilgisayarm yoktu. Sürekli internet kafeye gitmek zamanımı alıyordu. Olumlu yönü ise daha çok çalışmamı să̆ladı".

- Ö2: "Olumsuz yönünü bulamadım. Olumlu yönleri ise, ilk defa böyle ders işledik. Daha önceki dersler gibi değildi. Evde video izlerken sanki öğretmenimi yanımda hissettim. Bu model sayesinde hem okulda hem evde çalıştım".

şeklinde görüş belirtmiştir.

Araştırmaya katılanların ters yüz sınıf modelinin olumlu ve olumsuz yönleri ile ilgili görüşlerine bakıldığında, genel olarak araçların yetersizliği, yer sıkıntısının yaşanması olumsuz olarak değerlendirilirken, videoların süresinin kısa olması ve öğretmenin hem evde hem de okulda rehber olması bu modelin olumlu olduğunu ön plana çıartmıştır.

\section{Tartışma, Sonuç ve Öneriler}

Araştırmada nitel araştırma yöntemlerinden deneysel model kullanılmıştır. Araştırma sonucunda anlamlı bir öğrenimin gerçekleşip gerçeklemediğini ortaya çıkarmak için ön test ve son test uygulanmıştır. 
Ters yüz sınıf modelinin uygulandığı deney grubu ile MEB'in müfredatına uygun şekilde ders işlenen kontrol gruplarının ön test verileri arasında anlamlı bir fark bulunmamıştır. Dursunlar (2018) tarafından yapılan çalışmada, kontrol ve deney grupları arasında anlamlı bir farkın olmadığı tespit edilmiştir. Bunun sebebi olarak da dersi işlemeden önce bilgi düzeylerinin eşit olduğu düşüncesi öne sürülmüştür. Deney ve kontrol gruplarının son test verileri arasında ise anlamlı bir fark bulunmuştur. Başka bir ifadeyle ters yüz sınıf modelinin işlendiği deney grubu, MEB tabanlı yöntemle ders işleyen kontrol grubuna göre daha başarılı olmuştur. Bu sonuç, ders işlemede ters yüz sınıf modelinin daha etkili olduğunu göstermektedir. Gökdemir (2018), tarafından yapılan çalışma sonucunda, ters yüz sınıf modelinin uygulanmasının, öğretmen yetiştirme programlarında uygulanan geleneksel yöntemlere göre daha etkili bir yöntem olduğu sonucu elde edilmiştir. Bu da yapılan çalışmayı destekler niteliktedir.

Öztürk ve Alper (2019), tarafından yapılan çalışmada benzer sonuç elde edilmiştir. Sonuca göre; uygulama öncesinde kontrol ve deney gruplarına akademik başarı testi uygulanmış ve anlamlı bir fark bulunamamıştır. Bu sonuç uygulama öncesinde grupların eşit olduğunu göstermektedir. Uygulama sonrasında iki gruba akademik başarı testi uygulanmıştır. Başarı testi sonuçlarına göre ters yüz sınıf modeli uygulanan deney grubu öğrencilerinin akademik başarı puanları ile geleneksel öğretim yöntemi uygulanan kontrol grubu öğrencilerinin akademik başarı puanları arasında istatistiksel olarak anlamlı bir fark bulunmuştur. Deney grubu öğrencilerinin son test başarı puanı ortalaması kontrol grubu öğrencilerinin son test başarı puanı ortalamasına oranla daha yüksek bulunmuştur.

Deney ve kontrol gruplarında ön test ve son test puanlarının cinsiyete ve gelir ortalamalarına bakıldığında, bu ortalamalar arasında anlamlı düzeyde fark olmadığı tespit edilmiştir. Dursunlar (2018) tarafından yapılan çalışmada, cinsiyet değişkenine göre öğrencilerin akademik başarılarında anlamlı bir fark bulunmamıştır.

Kontrol grubunun ön test ve son test skorlarının internet kullanım düzeyine göre anlamlı bir fark göstermediği saptanmıştır. Deney grubunun ön test skorları da anlamlı bir fark göstermezken son test de anlamlı bir fark saptanmıştır. Kontrol grubu ve deney grubunun ön test skorlarının yaşanılan yere göre anlamlı bir fark göstermediği saptanmıştır. Deney grubunun son test skorlarına bakıldığında anlamlı bir fark görülmezken kontrol grubunun son 
test skorlarında anlamlı fark saptanmıştır. Sonuca bakıldığında ilçede yaşayan öğrencilerin merkezde yaşayan öğrencilere göre derslerinde daha başarılı olduğu tespit edilmiştir. Anne eğitim ve baba eğitim düzeyleri incelendiğinde deney ve kontrol grubunun ön test ve son test skorları anlamlı bir fark göstermemiştir. Bu çalışmada nicel araştırmanın yanında nitel araştırma da kullanılarak, araştırmada daha zengin veriler ve daha güvenilir sonuçlar elde edilmesi amaçlanmıştır. Nitel araştırmada verilerin toplanması için yarı yapılandırmış görüşme formu uygulanmıştır. Araştırmaya deney grubundan 11 öğrenci katılmıştır.

Öğrencilerin görüşlerine ilişkin elde edilen verilere göre; ters yüz sınıf modeli ile ilgili öğrencilerin genelinin eksiklikleri gidermek için önerilerde bulunduğu belirlenmiştir. Öğrencilerin bir kısmı, tablet dağıtımının yapılması, bilişim sınıflarından faydalanılması ve video içeriklerinin düzenlenmesini isterken, bazıları da bu modelin müfredatta yer almasını istediği sonucuna ulaşılmıştır. Önerilere bakıldığında genelde modelden çok öğrenmenin gerçekleşeceği ortamının yetersizlikleri üzerinde durdukları belirlenmiştir.

Araştırmaya katılanların etkin vatandaşlık öğrenme alanının, ters yüz sınıf modeline göre işlenmesinin derse olan ilgiyi arttırıp arttırmadığına ilişkin görüşlerine bakıldığında ise, genelinin bu modelin derse olan ilgilerini arttırdığ1 yönünde görüş belirttikleri saptanmıştır. Araştırmaya katılanların izlemiş oldukları videoların faydalı olup olmadığı ile ilgili görüşlerine bakıldığında ise, önceden hazırlanmış olan videoların içeriği ile ilgili olumlu yönde görüş belirtmişlerdir. Öğrencilerin ilk defa videodan ders işlemiş olmaları onların derse katılımlarını olumlu yönde etkilemiştir. İstedikleri zaman ve istedikleri yerde videoları tekrar izleyebilmeleri, derste işledikleri konuları unutmamaları için fayda sağlamıştır.

Araştırmaya katılanların evde yapılan etkinliklerin, öğretmen kontrolünde sınıf içerisinde yapılmasının, konunun kalıcılığını sağlayıp sağlamadığına ilişkin görüşlerine bakıldığında, ters yüz sınıf modelini beğendiklerini ve bu yöntemin konunun kalıcılığını arttırdığını belirtmişlerdir. Konular evde işlendiği için sınıf içerisinde bol etkinlik yapılmıştır ve etkinlik ile ilgili sorular öğretmen yardımı ile cevaplanmıştır. Karaman (2018) tarafından yapılan çalışmaya bakıldığında öğrencilerin sınıf içerisinde yaptıkları etkinlikler ile ilgili öğretmenden anında dönüt almalarının dersin kalıcılığını arttırdığı sonucuna ulaşılmıştır. Bu sonuç, deney grubunda uygulanan ters yüz 
sınıf modelinin öğrenme açısından kalıcilı̆ga olumlu yönde etki ettiği şeklinde yorumlanabilir.

Araştırmaya katılanların ters yüz sınıf modelinin olumlu ve olumsuz yönleri ile ilgili görüşlerine bakıldığında modelin olumsuzluklarının, olumlu yönlerine göre daha az olduğu sonucuna ulaşılmıştır. Çoğu öğrenciler, araç yetersizliğini ve ortam sıkıntısını olumsuz olarak değerlendirmiştir. Modelde konuların videoda anlatılması, video içeriklerinin öğrencinin düzeyine uygun olması ve öğretmenin rolü ise olumlu olarak değerlendirilmiştir. Bu sonuca da bakıldığında genel olarak katılımcların dile getirdiği eksiklikler giderildiğinde, bu model ile etkili bir öğrenme gerçekleştirilebilir. Kardaş ve Yeşilyaprak (2015) tarafından yapılan çalışmada, Ters yüz sınıf modeline ilişkin bazı olumsuzluklar şu şekilde sıralanmıştır; gerekli teknik alt yapı ve araçların eksiklikleri, videoların hazırlanmasında yaşanabilecek sıkıntılar ve video hazırlamanın zaman alması, öğrencilerin videoları izlemesiyle ilgili çalışma ve kontrollerin uzun sürebilecek olması. Literatürdeki bu çalışma ile yapılan bu çalışmanın sonuçlar açısından birbirini desteklediği söylenebilir.

Karaman (2018) tarafından yapılan çalışmaya bakıldığında ise; Ters yüz sınıf modelinin, öğrencilerin başarılarını arttırdığı ve derse yönelik olumlu değişmelerin meydana geldiği sonucuna ulaşılmıştır. Yine bu sonucu destekleyecek bir diğer çalışma ise Erdoğan (2018) tarafından yapılmıştır. Erdoğan (2008)'a göre Sosyal Bilgiler dersi öğrenciler tarafından oldukça zor ve sıkıcı bir ders olarak görülmektedir. Bunun nedenin ise ezber yapma gerekliliği ve geleneksel öğretim süreci olarak gösterilmektedir. Bu olumsuzlukları ortadan kaldırmayı ise teknoloji destekli öğretim süreci başarabilir. Böylece öğrencilerin derse yönelik olumsuz algıları yıkılabilir sonucuna ulaşmıştır.

Ters yüz edilmiş sınıf modeli ile ilgili olarak yapılan çalışmalara bakıldığında, çok farklı alan ve bölümlerde bu yöntemin kullanıldığı görülmektedir. Genel olarak ifade edilirse, hangi bölüm olursa olsun, öğrencilerin ters yüz edilmiş sınıf yöntemiyle öğrenim gördüklerinde, ders başarılarını arttırdıkları, derse daha çok motive oldukları görülmektedir (Seçemeli, 2016).

Ortaokul Sosyal Bilgiler dersi Etkin Vatandaşlık öğrenme alanında, ters yüz sınıf modelinin öğrenci akademik başarısına etkilerini ortaya koymak amacyyla yapılan araştırmanın bulgularına ilişkin öneriler aşağıda belirtilmiştir. 
- $\quad \mathrm{Bu}$ araştırmada ters yüz sınıf modelinin etkin vatandaşlık öğrenme alanının öğretiminde etkili olduğu sonucu elde edilmiştir. Dolayısıyla uygulayıclar sosyal bilgiler öğretiminde ters- yüz sınıf modeline yer verebilirler.

- Bu model, yeterli fiziksel altyapının sağlanmasını gerekli kılmaktadır. Dolayısıyla ters yüz sınıf modelinin etkili bir şekilde kullanılabilmesi için okulllar ve sinfflar ilgili modele uygun bir altyapıda dizayn edilebilir.

- Öğretmen hâlihazırda görev başında olan öğretmenlere ters -yüz sınıf modeli ile ilgili eğitimler verilebilir.

- Ters yüz sınıf modelinin, farklı yaş gruplarında ve farklı derslerde de uygulanıp etkililiği araştırılabilir. 


\title{
EXTENDED ABSTRACT
}

\section{The Effect of Using the Flipped Classroom Model in Teaching Active Citizenship Learning Area on Students' Academic Achievement}

\author{
Melike Söğüt - Suat Polat \\ Ağr İbrahim Çeçen University
}

The 21st century is seen as an era of many problems centered on human beings. At the heart of these problems are the actions that the individual has performed. Education lies at the basis of the problems of these individuals who make up the society. Therefore, the managers who make up the education system, education program, and educational institution are constantly scrutinized and changing (Şişman, 2012). The new generation of student profiles, called generation $Y$, finds the education system, which employs traditional methods, boring and adopts the education system in which technology is incorporated. That is why, the use of computers, tablets and the Internet has become widespread in the education system. Thus, it is possible to access information anytime and everywhere (Serçemeli, 2016). With the spread of technological innovations in education, the Internet and computer have started to be used in all of our fields of learning. Educators apply new and different learning models using technological tools and equipment. One of these learning models is the flipped classroom model (Kara, 2016). The concept of flipped means that the course that is traditionally held in the classroom is held at home and homework which is normally done at home is done in the classroom (Bergmann and Sams, 2012). In other words, it is called the flipped classroom model when the course that would be given by the instructor in the classroom is performed by the student outside the classroom, and the homework that would be done at home is done accompanied by a guide in the classroom. With this model of learning, active learning is transferred from teacher to student. (Pierce et al., 2012). In the traditional model, the transfer of the subject and its comprehension by the individual takes place in the classroom and its reinforcement takes place outside the classroom. In the flipped classroom model, the transfer and comprehension of information are carried 
out outside the classroom and the reinforcement of the subject is carried out in the classroom under the supervision of the guide (Gülşen and Otacioğlu 2017). For the last two decades, countries have sought to capture technological advances by making fundamental changes in their instructional programs. These changes made in all fields were also made in the field of Social Studies education. With these changes, it was aimed to eliminate the rote learning made in the Social Studies course and make it a course that the students could learn entertainingly (Ata, 2012). Teaching the course of Social Studies by using traditional methods may decrease the interest of individuals in the course. This can be eliminated by using the flipped classroom model. In order to increase the effectiveness of learning in the Social Studies course, the time-related problems arising from the intensity of the curriculum should be solved first. In the flipped classroom model, this problem is solved by doing the lesson at home and learning effectiveness can be ensured by doing more activities in the classroom (Karaman, 2018).

The aim of this study is to examine the effect of teaching the "Active Citizenship" learning domain of the secondary school 5th grade Social Studies course in accordance with the flipped classroom model on the academic success of the students. In the present research, the nested pattern which is one of the mixed-method designs was used. The mixed research method is a method consisting of a combination of quantitative and qualitative data. The pattern that involves the use of the data in a sequential or combined manner and addressing the main idea more comprehensively in one of the data is called a nested complex pattern (Creswell, trans; Bütün, 2014). The population of the study consisted of students studying in a secondary school in Ağr1 City Center in the 2018-2019 academic year. The sample of the study consisted of 88 randomly selected students from this secondary school. Experimental model was used in the quantitative stage of the research. Several designs are used in experimental research, but the most commonly used is the patterns consisting of two groups. One of these groups is called control group and the other is called experimental group (Özmen, 2014). The present study consisted of two groups. While the control group was taught the course by traditional methods, the experimental group was taught by the flipped classroom model. In the qualitative stage of the research, descriptive survey method was used. The data from the interview were obtained by performing the descriptive analysis. The interpretation of the data by the researcher without going into 
details is called descriptive analysis (Sönmez and Alacapınar, 2014). Eleven students constituting the experimental group participated in the interview.

As a result of the research, positive results were obtained that the flipped classroom model increases academic success according to the process determined in line with the curriculum by the Ministry of National Education. When the gender and income related mean scores of the pre-test and posttest results were examined in the experimental and control groups, no significant difference between these mean scores was found. The pre-test and posttest scores of the control group did not differ significantly in terms of internet usage level. There was no significant difference in the pre-test scores of the experimental group, while a significant difference was found in the post-test. The pre-test scores of the control group and the experimental group did not differ significantly in terms of the place of residence. There was no significant difference in the post-test scores of the experimental group, but a significant difference was found in the post-test scores of the control group. When the results were examined, it was found that the students living in the districts were more successful in their courses than the students living in the center. When the parents' education levels were examined, in terms of mother's education level, the pre-test and post-test scores of the experimental group did not show a significant difference, whereas a significant difference was found in the pre-test and post-test scores of the control group. The pre-test and posttest scores of the experimental and control groups did not show a significant difference in terms of father's education level. In the interview phase of the research, students expressed that they found the courses taught with the flipped classroom model generally enjoyable, that they learned with fun, and that the necessary tools and instruments should be provided for the effective implementation of this model.

\section{Kaynakça / References}

Akarsu, B. (2014). Hipotezlerin, değiş̧kenlerin ve örneklemin belirlenmesi. M. Metin (Ed). Kuramdan Uygulamaya Bilimsel Araştırma Yöntemleri. Ankara: Pegem Akademi.

Akbaba, B. ve Erdoğan, E. (2019). Ters yüz edilmiş sinif modeliyle ortaokul öğrencilerinin sosyal bilgiler dersi akademik başarılarının geliştirilmesi. Cumhuriyet Uluslararası Eğitim Dergisi, 8(1), 193-213. 
Arslantürk, Z. ve Arslantürk, A. (2013). Uygulamalı sosyal araştırma: kavramlar, teknikler, metotlar, bilgisayar uygulamaları, SPSS. (3. Baskı), İstanbul: Çamlica Yayınları.

Ata, B. (2012). Sosyal bilgiler öğretim programı. C. Öztürk (Ed.) Sosyal bilgiler öğretimi içinde (s.34). Ankara: Pegem Akademi.

Bergmann, J. ve Sams, A. (2012). In flip your classroom; reach every student, in every class, every day. USA:ISTE Washington. 13-16.

Büyüköztürk, Ş., Kılıç Çakmak, E., Erkan Akgün, Ö., Karadeniz, Ş. ve Demirel, F. (2012). Bilimsel araştırma yöntemleri. Ankara: Pegem Akademi.

Christen, L. B, Johnson, B. R. ve Turner, L. A. (2015). Araştırma yöntemleri deseni ve analiz (Çev. A. Aypay). Ankara: Anı Yayıncılık.

Creswell, J. W. (2014). Araştırma deseni. (Çev. Mesut Bütün), Ankara: Eğiten Kitap Yayınları.

Dursunlar, E. (2018). Ters yüz sınıf modelinin 7. sınıf sosyal bilgiler dersi yaşayan demokrasi ünitesinde öğrencilerin akademik başarısına etkisi. Yüksek Lisans Tezi. Atatürk Üniversitesi, Ankara.

Erdoğan, E. (2018). Sosyal bilgiler öğretiminde ters yüz edilmiş sinı modelinin kullanımı. Doktora Tezi. Gazi Üniversitesi Eğitim Bilimleri Enstitüsü, Ankara.

Gökdemir, A. (2018). Sosyal bilgiler öğretmeni yetiştirmede ters yüz öğrenme: bir karma yöntem çalışması. Doktora Tezi. Afyon Kocatepe Üniversitesi Sosyal Bilimler Enstitüsü, Afyon.

Gülşen, Otacıoğlu, A. S. ve Yıldız, Y. (2017). Flüt eğitiminde ters yüz öğrenme modelinin öğrenci başarısı üzerine etkileri. Route Educational and Social Science Journal. 4(6), 2017, 255.

Kara, C. (2016). Tıp fakültesi klinik eğitiminde "ters-yüz sınıf modeli" kullanılabilir mi?. Yüksek Lisans Tezi, Akdeniz Üniversitesi, Sağlık Bilimleri Enstitüsü, Antalya.

Karaman, B. (2018). Ters yüz sınıf modelinin sosyal bilgiler 7.sınf yaşayan demokrasi ünitesinde uygulanması. Yüksek Lisans Tezi. Adnan Menderes Üniversitesi Sosyal Bilimler Enstitüsü, Aydın.

Karasar, N. (1999). Bilimsel araştırma yöntemi. Ankara: Nobel Yayınları.

Kardaş, F. ve Yeşilyaprak, B. (2015). Eğitim ve öğretimde güncel bir yaklaşım: teknoloji destekli esnek öğrenme (flipped learning) modeli. Ankara Üniversitesi Ĕ̆itim Bilimleri Fakültesi Dergisi, 48(2), 103-121.

Lambert, V. A. ve Lambert, C. E. (2012). Qalitative descriptive research: an acceptable design. Pasific Rim International Journal of Nursing Research, 16(4), 255-256. 
Merrıam, S. B. (2015). Nitel araştırma desen ve uygulama için bir çeviri. (Çev. S. Turan). Ankara: Nobel Yayıncilık.

Özmen, H. (2014). Deneysel araştırma yöntemi. M. Metin (Ed). Kuramdan uygulamaya bilimsel araştırma yöntemleri. içinde(s.49). Ankara: Pegem Akademi.

Öztürk, S. ve Alper, A. (2019). Programlama öğretimindeki ters-yüz öğretim yönteminin öğrencilerin başarılarına, bilgisayara yönelik tutumuna ve kendi kendine öğrenme düzeylerine etkisi. Best Dergi. 3(1), 13-26.

Phillips, C. R. ve Trainor, J. E. (2014). Millennial students and the flipped classroom. Proceedins of ASBBS, 21, 519-530.

Serçemeli, M. (2016). Muhasebe eğitiminde yeni bir yaklaşım önerisi: Ters yüz edilmiş sinıflar. Muhasebe ve Finansman Dergisi, 116, 115-126.

Sönmez, V. ve Alacapınar, F. G. (2014). Bilimsel araştırma yöntemleri. Ankara: Anı Yayıncılık.

Şişman, M. (2012). Eğitim bilimlerine giriş. Ankara: Pegem Akademi.

Walker, R. (2012). Naturalistic research. J. Arthur, M. Woring, R. Coe and L. V. Hedges (Ed.). Research Methods and Methodologies in Education, içinde (s. 76-93). California: SAGE.

Yavuz, S. ve Coşkun, E. A. (2008). Sınıf öğretmenliği öğrencilerinin eğitimde teknoloji kullanımına ilişkin tutum ve düşünceleri. Hacettepe Üniversitesi Ĕ̆itim Fakültesi Dergisi, 34(34), 276-286.

\section{Kaynakça Bilgisi / Citation Information}

Söğüt, M. ve Polat, S. (2020). Ters-Yüz Sınıf Modelinin Etkin Vatandaşlık Öğrenme Alanının Öğretiminde Kullanılmasının Öğrencilerin Akademik Başarılarına Etkisi. OPUS-Uluslararası Toplum Araştırmaları Dergisi, 15(24), 2472-2504. DOI: 10.26466/opus. 658882 